\title{
Antigen-specific CD8+ memory stem T cells generated from human peripheral blood effectively eradicate allogeneic targets in mice
}

Liping Guan, Xiaoyi Li, Jiali Wei, Zhihui Liang, Jing Yang, Xiufang Weng ${ }^{*}$ and Xiongwen $\mathrm{Wu}^{*}$

\begin{abstract}
Background: As the implantation and long-term existence of tumor-specific T cells in host are the prerequisite for adoptive immunotherapy, memory stem T cells $\left(T_{S c M}\right)$ with self-renewal and differentiation capacity show the greatest potential to implant and long-term exhibit function in vivo, compared with other T cells of differentiation stages. Hence, tumor-specific $T_{\text {scm }}$ have become potential candidate for adoptive T cell therapy of cancer. Here, we reported a protocol to generate allogeneic antigen-specific CD8+ $T_{\text {SCM }}$ cells from human PBLs.

Methods: To prepare allogeneic antigen-specific CD8+ $\mathrm{T}_{\mathrm{SCM}}$, we used an LCL named E007 of defined HLA allotyping as simulator, a co-culture of E007 and allogeneic PBLs was carried out in the presence of differentiation inhibitor TWS119 for 7 days. Sorting of proliferation cells ensured the E007-specificity of the prepared TScM cells. The sorted lymphocytes underwent further expansion by cytokines IL-7 and IL-15 for further 7 days, making the E007specific CD8 $+T_{S C M}$ expanded in number. The stem cell and T memory cell properties of the prepared CD8 $+T_{S C M}$ were observed in NOD-SCID mice.

Results: Our protocol began with $1 \times 10^{7}$ PBLs and resulted in $2 \times 10^{7}$ E007-specific CD8 $+\mathrm{T}_{\mathrm{scm}}$ cells in 2 weeks of preparation. The prepared $T_{S C M}$ cells exhibited a proliferative history and rapid differentiation into effector cells upon the E007 re-stimulation. Importantly, the prepared $\mathrm{T}_{\mathrm{SCM}}$ cells were able to exist long and reconstitute other $\mathrm{T}$ cell subsets in vivo, eradicating the E007 cells effectively after transferred into the LCL burden mice.

Conclusions: This protocol was able to prepare allogeneic antigen-specific CD8+ $\mathrm{T}_{\mathrm{SCM}}$ cells from human PBLs. The prepared $\mathrm{T}_{\mathrm{SCM}}$ showed the properties of stem cells and T memory cells. This study provided a reference method for generation of antigen-specific $\mathrm{T}_{\mathrm{SCM}}$ for $\mathrm{T}$ cell adoptive immunotherapy.
\end{abstract}

Keywords: T memory stem cells, Allogeneic antigen specificity, Preparation in vitro, Adoptive immunotherapy

\section{Background}

Adaptive immunity is an effective strategy for cancer treatment. $\mathrm{T}$ cells are the main force to combat microbes and cancer cells in adaptive cells $[1,2]$. However, $T$ cell is heterogeneous, which exists in a continuum of differentiation states. According to differentiation stages, $\mathrm{T}$ cells can be divided into naive $\mathrm{T}$ cells $\left(\mathrm{T}_{\mathrm{N}}\right)$, memory stem cells $\left(\mathrm{T}_{\mathrm{SCM}}\right)$, central memory cells $\left(\mathrm{T}_{\mathrm{CM}}\right)$, effector

\footnotetext{
* Correspondence: wengxiufang@hust.edu.cn; xiongwenwu@hotmail.com Department of Immunology, School of Basic Medicine, Tongji Medical College, Huazhong University of Science and Technology, 13 Hangkong Rd, Wuhan 430030, China
}

memory cells $\left(\mathrm{T}_{\mathrm{EM}}\right)$ and differentiated effectors $\left(\mathrm{T}_{\mathrm{EF}}\right)[3$, 4]. Adoptive $\mathrm{T}$ cell therapy (ACT) for clinical application is normally based on the use of terminally differentiated $\mathrm{T}_{\mathrm{EF}}$ cells, which have short lifespan and inferior engraftment capacities [5-7]. $\mathrm{T}_{\mathrm{SCM}}$ is defined as the earliest developmental stage of memory $\mathrm{T}$ cells, which possesses capacities of self-renewal and differentiation $[5,8]$. Phenotypically, $\mathrm{T}_{\mathrm{SCM}}$ can be identified by the expression of CD3+ CD45RA+ CD62L+ CD95+ CCR7+ CD28+ [5, 9-11]. $\mathrm{T}_{\mathrm{SCM}}$ has longer lifespan, as it is reported $\mathrm{T}_{\mathrm{SCM}}$ is able to be tracked in vivo for 12 years after infusion of genetically modified lymphocytes [7]. In particular, $\mathrm{T}_{\mathrm{SCM}}$ 
mediates longer and more robust efficiency of tumor rejection in vivo compared to other memory and effector subsets $[5,6,8,12-14]$. It is these characteristics that make $\mathrm{T}_{\mathrm{SCM}}$ a good candidate for immunological cytotherapy of cancer.

$\mathrm{T}_{\mathrm{SCM}}$ constitutes a small proportion of the $\mathrm{T}$ cell subset, $2-4 \%$ of the total $\mathrm{T}$ cells in peripheral blood $[5,8]$. The premise of antigen-specific $\mathrm{T}_{\mathrm{SCM}}$ used for clinical therapy is to accomplish in vitro $\mathrm{T}_{\mathrm{SCM}}$ preparation in a large number. It is demonstrated that small molecule chemical inhibitor TWS119, a potent inhibitor of the serine-threonine glycogen synthase kinase $3 \beta$ (GSK-3 $\beta$ ) able to induce the Wnt- $\beta$-catenin signaling, helps the enrichment of $\mathrm{T}_{\mathrm{SCM}}$ through differentiation inhibition both in mice and in human [15-17]. On the other hand, $\mathrm{T}_{\mathrm{SCM}}$ can be amplified with cytokines IL-7 and IL-15; IL-21 is also reported to promote the generation of $\mathrm{T}_{\mathrm{SCM}}$ under ex vivo culture conditions $[6,18-26]$.

Allogeneic hematopoietic stem cell transplantation (allo-SCT) is an effective immunotherapeutic approach with curative potential in patients with malignancies. The therapeutic basis is mainly dependent on the donor $\mathrm{T}$ cell alloresponses against the recipient's malignant cells named as graft versus leukemia (GVL) or graft versus tumor (GVT) effect [27]. T cell responses to alloantigen are of peptide-MHC complex (pMHC) specificity in the same way as those to nominal antigen $[28,29]$. Transfer of alloreactive $\mathrm{T}$ cells with defined specificity, such as for leukemia- or tumor-associated antigens, is proposed to separate the GVL or GVT effect from the deleterious graft versus host disease (GVHD) [30, 31]. As the implantation and long-term existence of tumor-specific $\mathrm{T}$ cells in host are the prerequisite for adoptive immunotherapy, it is of importance to prepare alloantigen-specific $\mathrm{T}_{\mathrm{SCM}}$ cells in vitro.

In this study, we explored a methodology of alloantigen-specific $\mathrm{T}_{\mathrm{SCM}}$ (allo-specific $\mathrm{T}_{\mathrm{SCM}}$ ) preparing in vitro. Although both $\mathrm{CD} 4+$ and $\mathrm{CD} 8+\mathrm{T}_{\mathrm{SCM}}$ cells are reported, we focused on CD8 $+\mathrm{T}_{\mathrm{SCM}}$ cells. The $\mathrm{T}_{\mathrm{SCM}}$ cells were generated in an allogeneic co-culture, enriched by TWS119, then sorted with proliferation, and finally expanded by IL-7 and IL-15. Our protocol prepared $2 \times 10^{7}$ allo-specific $\mathrm{T}_{\mathrm{SCM}}$ cells from $1 \times 10^{7}$ PBLs. An LCL burden mouse model was introduced in for the $\mathrm{T}_{\mathrm{SCM}}$ cell behavior in vivo. LCL cells were human $\mathrm{B}$ lymphoblastoid cells immortalized by EB virus infection. Although this model would reflect lymphoproliferative disorders, the LCL cells in mice could act as allogeneic targets to measure eradication efficacy of $\mathrm{T}$ cells in vivo in our study. Importantly, the prepared $\mathrm{T}_{\mathrm{SCM}}$ cells exhibited both stem cell and memory $\mathrm{T}$ cell properties, and were able to implant and effectively eradicate the targets after adoptive transfer into mice. This study provided a practical method for generation of allo-specific
$\mathrm{T}_{\mathrm{SCM}}$ cells in vitro, which would be expected to be referred in preparation of allogeneic $\mathrm{T}_{\mathrm{SCM}}$ grafts with defined antigen specificity for the purpose of adoptive immunotherapy.

\section{Materials and methods \\ Peripheral blood lymphocyte isolation}

Peripheral blood was obtained from healthy donors after informed consent under a protocol approved by the Ethics Committee of Tongji Medical College, Wuhan, China. Peripheral blood mononuclear cells (PBMCs) were isolated by centrifugation through a ficoll-hypaque gradient (Ficoll-Hypaquedensity $1.077 \mathrm{~g} / \mathrm{ml}$ ) and cultured in RPMI-1640 medium supplemented with 10\% fetal bovine serum (FBS), then placed in dish for $2 \mathrm{~h}$ to remove the adherent cells. The non-adherent cells were collected as peripheral blood lymphocytes (PBLs) for the co-culture.

\section{Cell lines and antibodies}

The EB virus (EBV) transformed B lymphoblastoid cell lines (LCLs) E007 and E001 were established in our lab according to reported protocol [32]. HLA typing for LCLs was performed with PCR-SSP [33]. The HLA class I alleles of E007 and E001 are mismatched, E007 carried

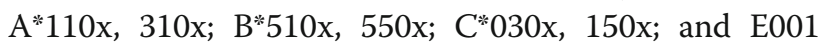

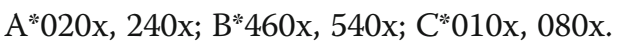

Fluorescent antibodies for cells staining included human CD3-APC-Cy7 (clone HIT3a), CD8-BV510 (clone SK1), CD3-Percp-Cy5.5 (clone HIT3a), CD62L-PE-Cy7 (clone DREG-56), CD45RA-APC (clone HIT100), CD45RA-BV421 (clone HI100), CD95-PE (clone DX2), CXCR7-PE (clone 10D1-J16), CD28-APC (clone CD28.2), IL-2-APC (clone MQ1-17H12), IFN- $\gamma$-PE (clone 4S.B3), TNF- $\alpha$-PE (clone MAb11), the above antibodies were purchased from BioLegend, USA. Corresponding isotype for each antibody were used as isotype control. Cells were analyzed on a BD LSR flow cytometer. $\mathrm{T}$ cell subsets were determined using fluorescence minus one (FMO) controls for interesting antibody.

\section{Allogeneic co-culture and allo-specific $\mathrm{T}_{\mathrm{SCM}}$ preparation} Allogeneic PBLs were co-cultured with the E007 for raising alloreactive $\mathrm{T}_{\mathrm{SCM}}$ cells. PBLs were stained with $5 \mu \mathrm{M}$ carboxyfluorescein diacetate succinimidyl ester (CFSE, sigma) for $8 \mathrm{~min}$ at $37^{\circ} \mathrm{C}$ and washed with RPMI1640 supplemented with 10\% FBS three times. E007 were inactivated by irradiating $(2.0 \mathrm{~Gy})$. PBLs were mixed with E007 on day 0 at a ratio of $5: 1$ with $5 \mu \mathrm{M}$ TWS119 in the co-culture for the first week. PBLs cultured alone used as control. TWS119 and medium were replaced on day 4, and cells were counted by Trypan blue dye exclusion. As the allo-specific $\mathrm{T}$ cells showed 
proliferation in the co-culture, CFSEdim cells were sorted by FACS with BD FACS AriaII on day 7. Sorted cells were expanded by cytokines IL-7 and IL-15 (Peprotech, USA) of $25 \mathrm{ng} / \mathrm{ml}$ each for a further week.

$\mathrm{T}$ cell subsets in the co-culture bulks were identified by their surface markers, CD3+ CD8+ CD45RA+ $\mathrm{CD} 62 \mathrm{~L}+\mathrm{CCR} 7+\mathrm{CD} 95+\mathrm{CD} 28+$ for $\mathrm{T}_{\mathrm{SCM}}$, CD3+ CD8+ CD45 RA- CD62L+ for $\mathrm{T}_{\mathrm{CM}}$, CD3+ CD8+ CD45RACD62L- for $\mathrm{T}_{\mathrm{EM}}$, and CD3+ CD8+ CD45 RA+ CD62Lfor $\mathrm{T}_{\mathrm{EF}}$.

Preparation of allo-specific $\mathrm{T}_{E M}$ and $\mathrm{T}_{\mathrm{EF}}$ for mouse transfer Allo-specific $T_{E M}$ and $T_{E F}$ cells were prepared by a co-culture of allogeneic PBLs with E007 set up as above, but no TWS119 was added. CFSEdim cells were sorted on day 7. Sorted cells were further expanded by $300 \mathrm{U} /$ ml IL-2 (Peprotech, USA) instead of IL-7 and IL-15 for a further week.

\section{In vitro $\mathrm{T}_{\mathrm{SCM}}$ cells differentiation assay and intracellular cytokine staining}

The prepared $\mathrm{T}_{\mathrm{SCM}}$ cells were incubated with E007, E001 cells and Dynabeads Human T-Activator CD3/CD28 $(\alpha-\mathrm{CD} 3 / \mathrm{CD} 28)$ (Gibco, USA), respectively, in a 5:1 ratio. Cells were collected at 6,12 , and $24 \mathrm{~h}$, and labeled with corresponding fluorescent antibodies for differentiation assay. The $\mathrm{T}_{\mathrm{SCM}}$ cells incubated with the above stimulations in the presence of $1 \times$ BFA (eBioscience, USA) were collected for intracellular IFN- $\gamma$, IL-2, and TNF- $\alpha$ staining after $4 \mathrm{~h}$ incubation. Samples were analyzed on BD Verse flow cytometer. The data analysis was performed with Flowjo software version 10.0 (Tree Star).

\section{Quantitative real-time PCR}

$\mathrm{T}$ cell subsets in the co-culture were sorted by $\mathrm{BD}$ Aria II flow cytometer based on the corresponding phenotypes on day 7. Total DNA of the T cells was isolated using a genomic Extraction kit (Takara, Japan), following manufacturer's instructions. TRECs of T cell subsets were detected using fluorescently quantitative PCR kit (Takara, Japan) with TREC-specific primers [34] on Bio-Rad CFX Sequence detection system.

\section{Animal experiments}

6-week-old female NOD-SCID mice were purchased from Vital River Lab Animal Co, Ltd. (Beijing; a distributor of the Jackson Laboratory). Animal experiments in this study were approved by the Ethical Committee of Tongji Medical College. The mice were irradiated with 2.0 Gy and randomized in five groups $(n=5)$, then intravenous injection with $8 \times 10^{6}$ E007 or E001 on day -3 . The mice were injected with the $1 \times 10^{7}$ allo-specific $\mathrm{T}_{\mathrm{SCM}}$ or allo-specific $\mathrm{T}_{\mathrm{EM}}$ and $\mathrm{T}_{\mathrm{EF}}$ on day 0 . Blood samples were taken every week from mice after the $\mathrm{T}$ cell transfer. The number and phenotype of human $\mathrm{T}$ cells in mouse peripheral blood were determined by flow cytometry. The signs of GVHD were monitored daily. Mice were euthanized on day 35 and bone marrow and spleen were removed to detect human $\mathrm{T}$ cells and residual LCL cells. The LCL cells were detected by the latent membrane protein 1 (LMP1) of EB virus using antibodies LMP1-FITC (primary antibody: mouse anti-EBV LMP1, clone CS1-4, Abcom; secondary antibody: goat anti-mouse IgG-FITC, clone poly 4053, BioLegend) and flow cytometry.

\section{Immunofluorescence analysis for mouse spleen}

Formaldehyde-fixed spleen specimens were embedded in paraffin and cut into sections for immunofluorescent detection of human CD3+ T cells with antibodies CD3-488 (primary antibody: rabbit anti-human CD3, clone SP7, ThermoFisher; secondary antibody: goat anti-rabbit $\lg G$ H\&L-Alexa Fluor 488, Abcom) and LMP1-CY3 (secondary antibody: goat anti-mouse lgG H\&L-Cy3, Abcom) respectively. Nuclei were stained with DAPI (BioLegend).

\section{Statistical analysis}

The statistical significance of differences between two groups was assessed with a 2-tailed paired or unpaired $t$ test. Comparisons of more than two groups were performed by one-way ANOVA with multiple comparison tests. Data are shown as the mean \pm standard deviation (SD). Difference were marked as NS, $P>0.05 ;{ }^{*} P<0.05$; ${ }^{* *} P<0.01$, and ${ }^{* * *} P<0.001$. All the data obtained from the study was analyzed using SPSS 22.0 (IBM, USA).

\section{Results}

Our in vitro protocol is able to prepare allo-specific CD8+ $\mathrm{T}_{\mathrm{SCM}}$ cells effectively

To prepare allo-specific $\mathrm{T}_{\mathrm{SCM}}$, this study began with a co-culture of a simulator cells and allogeneic PBLs on day 0 . The stimulator was an LCL named as E007 with defined HLA allotyping. Due to the difference in HLA alleles among random donors, allo-specific $\mathrm{T}_{\mathrm{SCM}}$ cells were generated from $\mathrm{T}_{\mathrm{N}}$ through proliferation during the co-culturing (Fig. 1a). The $\mathrm{T}_{\mathrm{SCM}}$ were enriched in the presence of differentiation inhibitor TWS119, of which the optimal concentration was $5 \mu \mathrm{M}$ in the allogeneic co-culture (Additional file 1: Figure S1A B). On day 7 , the $\mathrm{T}_{\mathrm{SCM}}$ cells in the co-culture bulks were defined by the phenotype CD3+ CD8+ CD45RA+ CD62L+ CD95+ CCR7 + CD28+ (Fig. 1b). The inhibition of differentiation in the allogeneic co-culture enriched the $\mathrm{T}_{\mathrm{SCM}}$ numbers by 100 folds on day 7 (Fig. 1c). As the allo-specific $\mathrm{T}$ cells showed proliferation in the co-culture, sorting of proliferation cells ensured the antigen-specificity of the prepared $\mathrm{T}_{\mathrm{SCM}}$ cells. The 


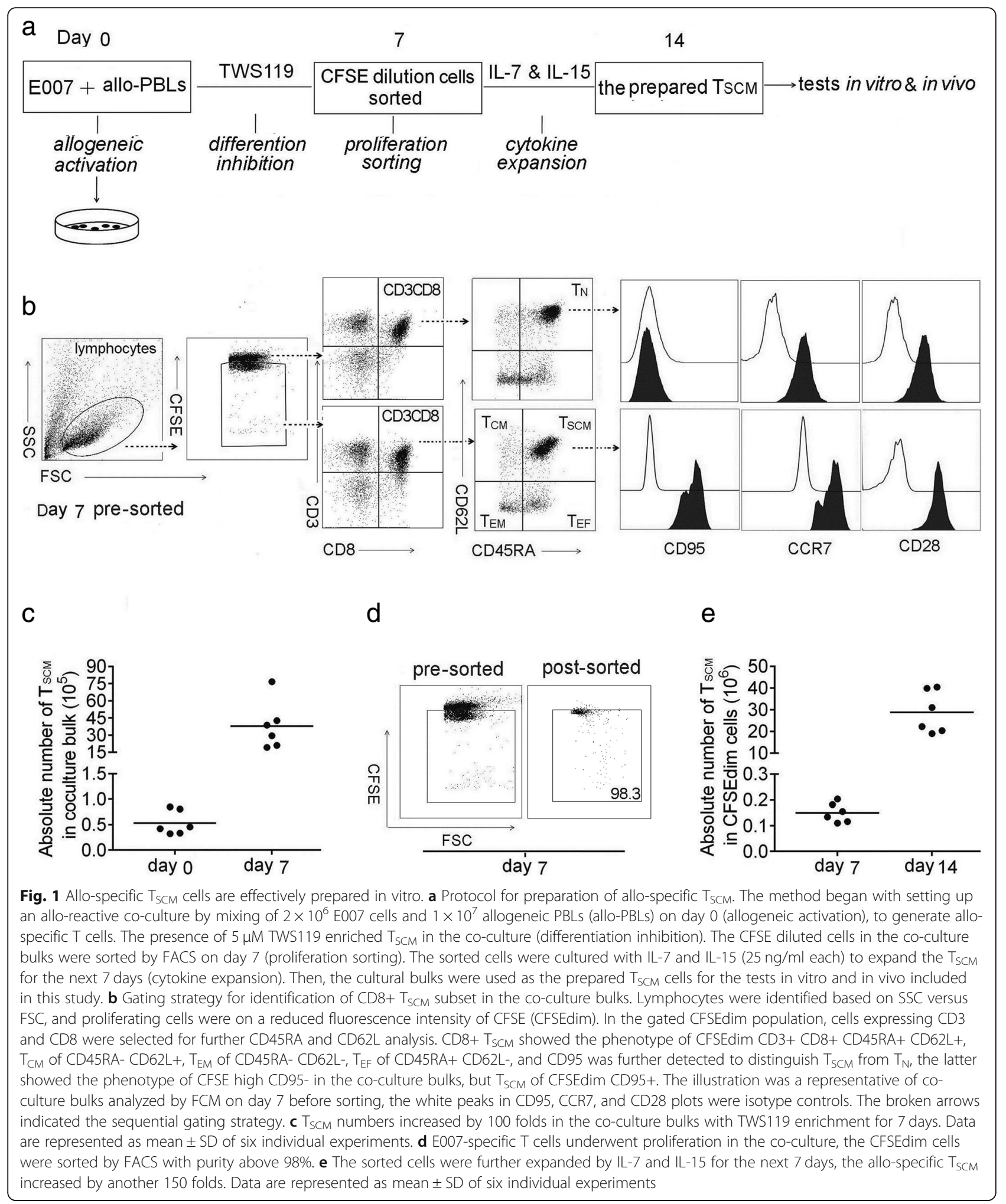

sorting reached above $98 \%$ purity of the proliferative cells (Fig. 1d). It would be rational that the prepared $\mathrm{T}_{\mathrm{SCM}}$ cells were E007 specific. After sorting, the cells were cultured in the presence of IL-7 and IL-15 (25 ng/ $\mathrm{ml}$ each) for the next 7 days. The allo-specific $\mathrm{T}_{\mathrm{SCM}}$ increased by another 150 folds on day 14 (Fig. 1e). The lymphocyte distribution at this time not only showed the cultural bulks were mainly $\mathrm{CD} 8+\mathrm{T}_{\mathrm{SCM}}(60.1 \pm 11.2 \%)$, 
but also contained a few CD4+ $\mathrm{T}_{\mathrm{SCM}}(10.4 \pm 8.16 \%)$, CD3- cells $(6.15 \pm 5.23 \%), \quad \mathrm{CD} 8+$ non- $\mathrm{T}_{\mathrm{SCM}}(12.6 \pm$ $3.48 \%$ ), and $\mathrm{CD} 4+$ non- $\mathrm{T}_{\mathrm{SCM}}(10.2 \pm 8.66 \%)$ cells (Additional file 1: Figure S1D E F). By allogeneic activating, inhibiting differentiation with TWS119, sorting CFSEdim cells, and expansion with IL-7 and IL-15, our in vitro protocol was able to prepare about $2 \times 10^{7}$ allo-specific CD8 $+\mathrm{T}_{\mathrm{SCM}}$ cells from $1 \times 10^{7}$ PBLs. The number of the $\mathrm{T}_{\mathrm{SCM}}$ cells was sufficient to meet the needs of the following studies.

The $\mathrm{T}_{\mathrm{SCM}}$ preparation strategy used in this study could be translated into a single epitope-specific $\mathrm{T}_{\mathrm{SCM}}$ preparation. When the E007 co-cultured with allogeneic PBLs, the precursor frequencies were much higher than those of $\mathrm{T}$ cell responses to a single allogeneic epitope. To prepare a single epitope-specific $\mathrm{T}_{\mathrm{SCM}}$ cells in a large number, a modification with a prolonged cytokine expansion was required (Additional file 2: Figure S2).

\section{The prepared $\mathrm{T}_{\mathrm{SCM}}$ cells show stem cell and memory $\mathrm{T}$ cell characteristics in vitro}

To examine the self-renewal capacity, $\mathrm{T}_{\mathrm{N}}, \mathrm{T}_{\mathrm{SCM}}, \mathrm{T}_{\mathrm{CM}}$, and $\mathrm{T}_{\mathrm{EM}}$ cells were sorted by their corresponding phenotypes from the co-culture on day 7 (Fig. 1b). The content of $\mathrm{T}$ cell receptor rearrangement excision circles (TRECs) in each subset was examined by real-time qPCR. As TRECs cannot be replicated while cell division, the content of TRECs reflects the frequency of $\mathrm{T}$ cell proliferation. Results showed that $\mathrm{T}_{\mathrm{N}}$ had the highest content of TRECs. $\mathrm{T}_{\mathrm{SCM}}, \mathrm{T}_{\mathrm{CM}}$, and $\mathrm{T}_{\mathrm{EM}}$ cells possessed less TRECs, confirming they were differentiated from $\mathrm{T}_{\mathrm{N}}$ through $\mathrm{T}$ cell clonal proliferation (Fig. 2a). The content of TRECs in $\mathrm{T}_{\mathrm{SCM}}$ cells was between those of $\mathrm{T}_{\mathrm{N}}$ and $\mathrm{T}_{\mathrm{CM}}$ cells, suggesting $\mathrm{T}_{\mathrm{SCM}}$ was at the earliest stage after $\mathrm{T}_{\mathrm{N}}$ activation.

The prepared $\mathrm{T}_{\mathrm{SCM}}$ cells were relabeled with CFSE and exposed to IL-2 (200 U/ml) for 10 days. As IL-2 is a potential promoter for $\mathrm{T}$ cell proliferation and differentiation, seven generations of CFSE-diluted daughter cells developed. A portion of $\mathrm{T}_{\mathrm{SCM}}$ cells (CD45RA+ CD62L+) were found in each generation, indicating that the prepared $\mathrm{T}_{\mathrm{SCM}}$ cells were able to maintain a stem cell phenotype during proliferation and differentiation (Fig. 2b, c). Collectively, the prepared $\mathrm{T}_{\mathrm{SCM}}$ cells showed characteristics of self-renewal.

To check memory $\mathrm{T}$ cell characteristics, the prepared $\mathrm{T}_{\mathrm{SCM}}$ cells were incubated with the cognate stimulator E007, HLA class I mismatched E001, and $\alpha-C D 3 / C D 28$ beads. Phenotypic analysis revealed that the E007-restimulated $\mathrm{T}_{\mathrm{SCM}}$ cells showed vigorous differentiation in $6 \mathrm{~h}$, which became more intensive with prolonged stimulation time. A similar response was observed in the $\alpha$-CD3/CD28-stimulated $\mathrm{T}_{\mathrm{SCM}}$ cells. While the E001-stimulated $\mathrm{T}_{\mathrm{SCM}}$ cells showed no significant differentiation after $24 \mathrm{~h}$, the response was similar to that of non-stimulated $\mathrm{T}_{\mathrm{SCM}}$ cells (Fig. 3a, b). In addition, after $24 \mathrm{~h}$ of incubation with E007 and $\alpha-C D 3 / C D 28$, we found that $\mathrm{T}_{\mathrm{SCM}}$ cells in the incubation showed no significant change in absolute number (Additional file 3: Figure S3E), suggesting that $\mathrm{T}_{\mathrm{SCM}}$ cells were able to self-renew during proliferation and differentiation.

CD8 + $\mathrm{T}$ cell mediated immune effectors include production of cytokines and killing of target cells. To investigate production of cytokines, the $\mathrm{T}_{\mathrm{SCM}}$ cells were stimulated with E007, E001, and $\alpha-\mathrm{CD} 3 / \mathrm{CD} 28$ beads, then intracellular IL-2, TNF- $\alpha$, and IFN- $\gamma$ production was measured. The E007-restimulated $\mathrm{T}_{\mathrm{SCM}}$ cells showed more positive cells of these cytokines. Gating with $\mathrm{CD} 62 \mathrm{~L}$, the incubated bulks were divided into CD62L+ $\left(\mathrm{T}_{\mathrm{SCM}}\right.$ and $\left.\mathrm{T}_{\mathrm{CM}}\right)$ and CD62L- $\left(\mathrm{T}_{\mathrm{EM}}\right.$ and $\left.\mathrm{T}_{\mathrm{EF}}\right)$ cells, most of the cytokine positive cells were $\mathrm{T}_{\mathrm{EM}}$ and $\mathrm{T}_{\mathrm{EF}}$ cells (Fig. 3c). Meanwhile, gating with CD45RA, we found that both $\mathrm{T}_{\mathrm{EM}}$ and $\mathrm{T}_{\mathrm{EF}}$ cells showed similar frequency of the cytokine positive cells (Additional file 3: Figure S3A-D). Whereas, the $\mathrm{T}_{\mathrm{SCM}}$ cells in the incubation produced almost background IL-2, and only a low level of TNF- $\alpha$ and IFN- $\gamma$. The $\mathrm{T}_{\mathrm{SCM}}$ cells responded against $\alpha-C D 3 / C D 28$ in a similar profile of the cytokine production to that against E007. In contrast, the $\mathrm{T}_{\mathrm{SCM}}$ cells stimulated with E001 showed frequency of cytokine-positive cells in the same way as that with non-stimulation (Fig. 3c-f). Next, we moved to cytotoxicity assay, the $\mathrm{T}_{\mathrm{SCM}}$ co-cultured with E007 or E001 for $24 \mathrm{~h}$ at a ratio 5:1. Killing rate of the $\mathrm{T}_{\mathrm{SCM}}$ and daughter cells against E007 was higher than that against E001 after $8 \mathrm{~h}$ (Additional file 3: Figure S3F, G). These results showed that the prepared $\mathrm{T}_{\mathrm{SCM}}$ cells were E007-specific and able to differentiate rapidly into effector $\mathrm{T}$ cells after stimulated by the same antigen.

\section{The prepared $\mathrm{T}_{\mathrm{SCM}}$ cells are able to implant and effectively remove target cells in vivo}

To evaluate capacity of persistence and rejecting target cells in vivo of the prepared $\mathrm{T}_{\mathrm{SCM}}$ cells, human $\mathrm{LCL}$ cells E001 or E007 were inoculated intravenously into NOD/SCID mice to establish LCL-burden mouse model. After 3 days, the LCL-burden mice were treated with either E007-specific $\mathrm{T}_{\mathrm{SCM}}$ cells or E007-specific $\mathrm{T}_{\mathrm{EM}}$ and $\mathrm{T}_{\mathrm{EF}}$ cells (Fig. 4a, b). On days 7, 14, 21, 28, and 35 after $\mathrm{T}$ cell infusion, caudal vein peripheral blood samples were taken to detect the frequency and phenotype of human $\mathrm{T}$ cells. We found human CD3+ CD8+ T cells in the peripheral blood of the $\mathrm{T}_{\mathrm{SCM}^{-}}$-treated mice at all

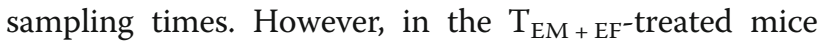
$\left(\mathrm{E} 007-\mathrm{T}_{\mathrm{EM}+\mathrm{EF}}\right)$, human $\mathrm{T}$ cells were detected in peripheral blood on day 7, but not on day 14 or later (Fig. 4c). In the $\mathrm{T}_{\mathrm{SCM}^{-}}$-treated mice, the frequency of $\mathrm{T}_{\mathrm{SCM}}$ cells in 

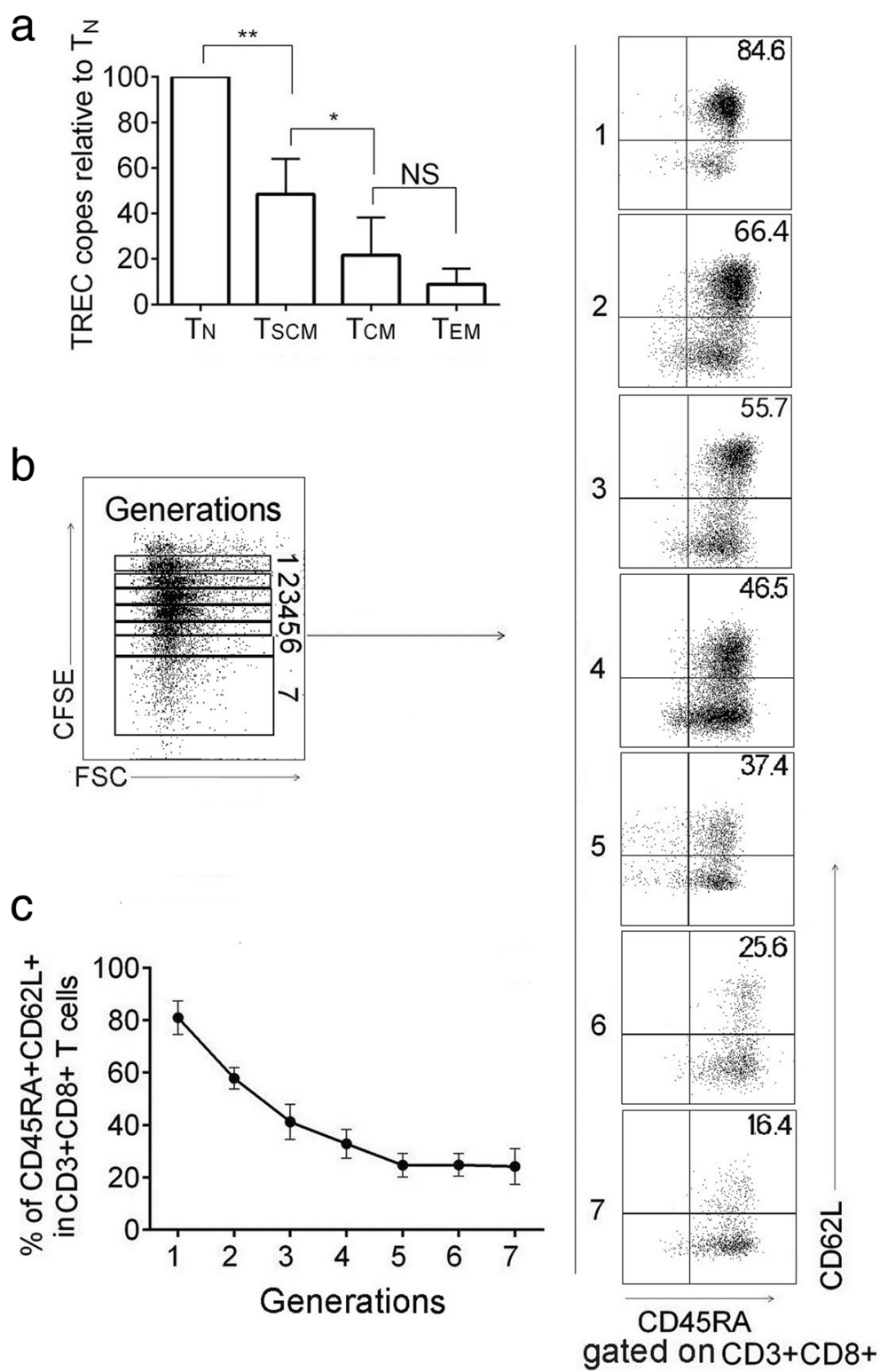

Fig. 2 The prepared $T_{S C M}$ cells bear the ability of self-renewing. a $T_{N}, T_{S C M}, T_{C M}$, and $T_{E M}$ cell subsets in CD8+ T cells were sorted by their corresponding phenotypes from the co-culture on day 7. TREC copy number in the sorted subsets relative to $T_{N}$ cells was shown. Data are represented as mean \pm SD of four individual experiments. $\mathbf{b}$ The prepared TSCM cells were relabeled with CFSE and exposed to $200 \mathrm{U} / \mathrm{ml}$ of IL-2 for 10 days, the proliferating daughter cells divided into 7 generations (left panel). In each generation, there were a portion of CD8+ T cells expressing CD62L and CD45RA (right panel). Representative FCM plots were shown. $\mathbf{c}$ The frequency of $T_{S C M}(C D 45 R A+C D 62 L+)$ cells in CD8+ T cells was analyzed at each CFSE dilution peak. Data are represented as mean \pm SD of four individual experiments. $\left({ }^{*} p<0.05\right.$; ${ }^{* *} p<0.01$, and $\mathrm{NS}, p>0.05)$

the E007-burden mice (E007- $\left.\mathrm{T}_{\mathrm{SCM}}\right)$ were lower than that in the E001-burden mice (E001- $\mathrm{T}_{\mathrm{SCM}}$ ), but no difference was found in the absolute number of $\mathrm{T}_{\mathrm{SCM}}$ cells between E007-burden and E001-burden mice (Fig. 4d, e). On day 35 , more frequent human $\mathrm{T}$ cells were found in the spleen and bone marrow of the $\mathrm{T}_{\mathrm{SCM}^{-}}$-treated mice revealed by flow cytometry (Fig. 5a), and the immunofluorescent staining of the spleen sections showed the similar results (Fig. 6d, e). These findings indicated that the $\mathrm{T}_{\mathrm{SCM}}$ cells were able to survive long through self-renewal in the mice, and differentiate into other $\mathrm{T}$ cell subsets as stimulated with the specific antigens of E007.

To investigate the immune reconstitution capacity of the $\mathrm{T}_{\mathrm{SCM}}$ cells, peripheral blood, spleen, and bone mar-

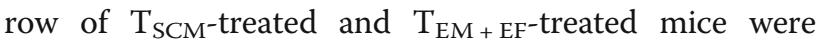
tested for human $\mathrm{T}$ cells on day 35 . The human $\mathrm{T}$ cells in the above specimens consisted of $\mathrm{T}_{\mathrm{SCM}}$ (CD45RA + 

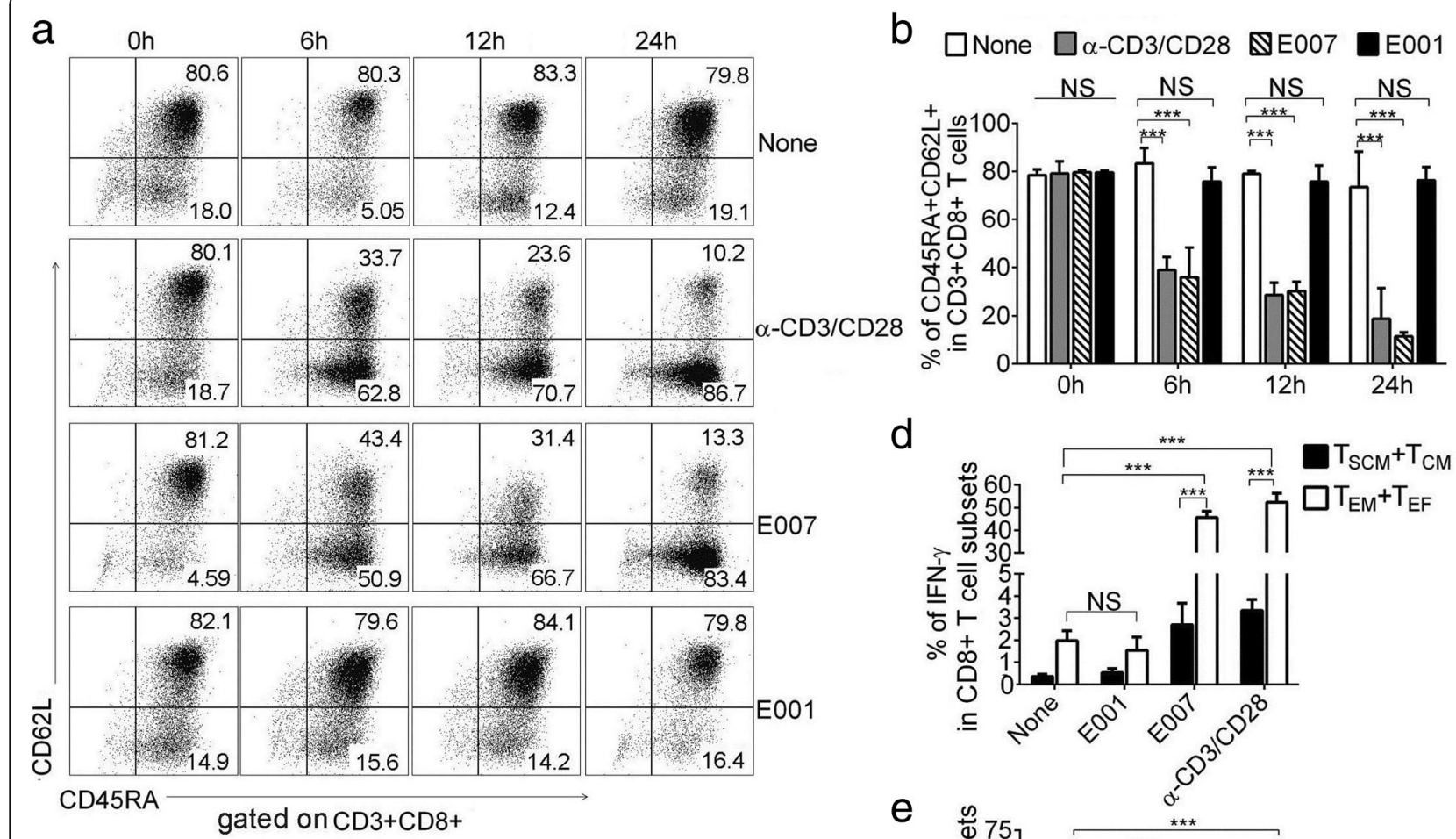

d

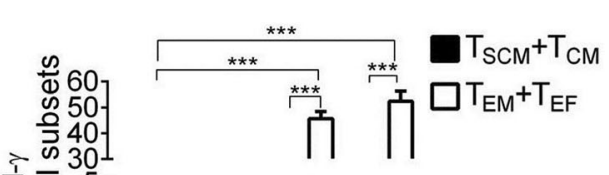

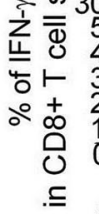

e
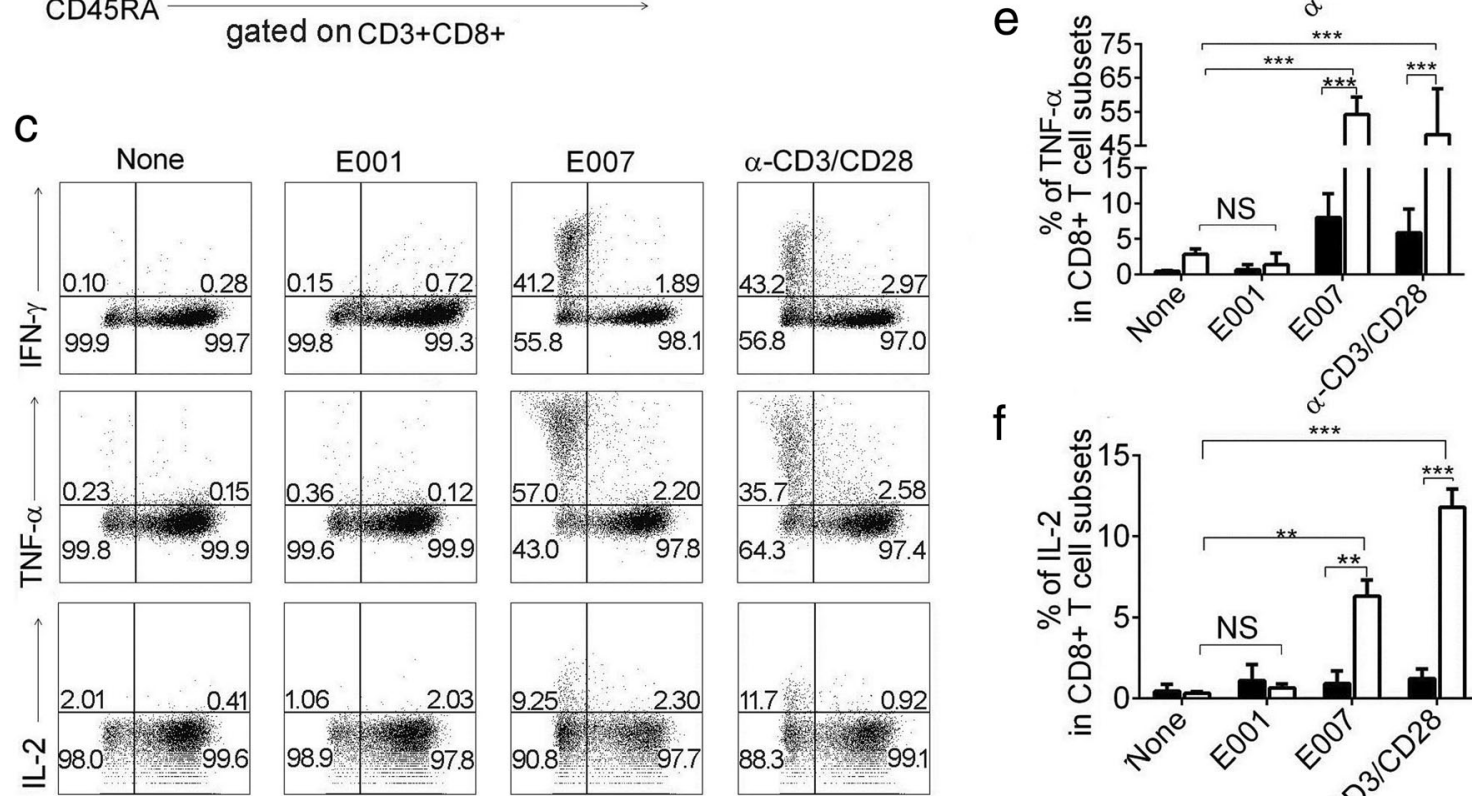

gated onCD3+CD8+

Fig. 3 E007 cells stimulate the $T_{S C M}$ differentiate rapidly and the daughter effectors produce cytokines. The prepared $T_{S C M}$ were stimulated with E007, E001, and a-CD3/CD28, respectively. a, b The Tscm differentiated into effector T cells upon the stimulation with E007. CD3+ CD8+ T cells expressing CD45RA and CD62L ( $T_{\text {SCM }}$ cells) were detected at indicated hours after stimulation. Representative FCM plots were shown (a). Data are represented as mean \pm SD of four individual experiments $(\mathbf{b})$. c-f Effector T cells differentiated from the $T_{S c m}$ produced cytokines. Intracellular IL-2, TNF- $a$, and IFN- $\gamma$ production of the T cell subsets were detected. Gating by CD62L, the T cells were divided into CD62L+ ( $T_{S C M}$ and $\left.T_{C M}\right)$ and CD62L- ( $T_{E M}$ and $T_{E F}$ ) cells, the $T_{E M}$ and $T_{E F}$ subsets showed the cytokine positively stained cells. Representative FCM plots (the percentages indicated the cytokine producing cells in CD62L+ and CD62L-cells, respectively) (c) and the frequencies of IFN- $($ (d), TNF-a (e) and IL-2 (f) positive cells in corresponding CD8+ T cell subsets were shown. Data are represented as mean \pm SD of four individual experiments $(* * p<0.01$; ${ }^{* * *} p<0.001$, and NS, $\left.p>0.05\right)$ 


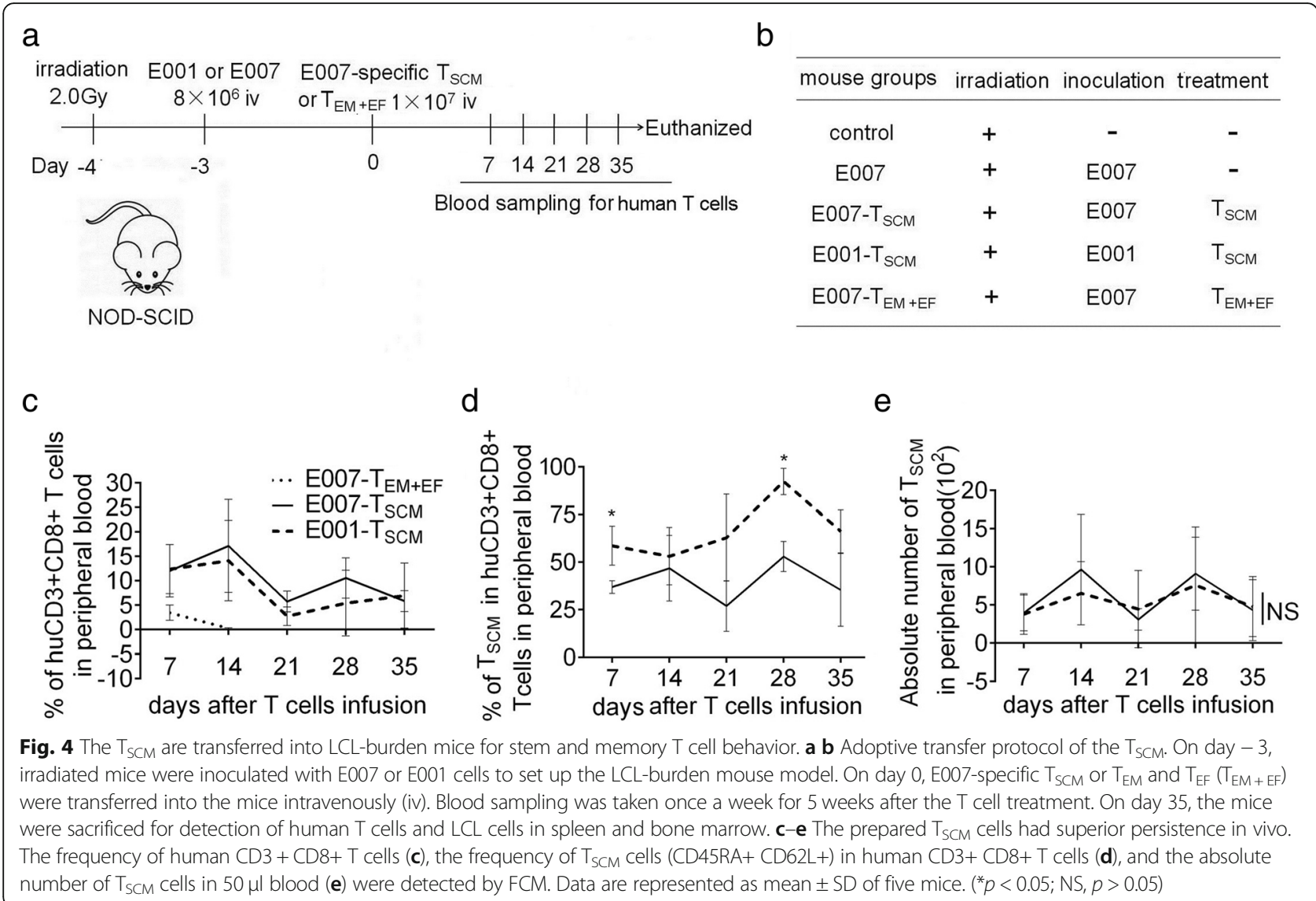

CD62L+), $\quad \mathrm{T}_{\mathrm{CM}} \quad$ (CD45RA-CD62L+), $\quad \mathrm{T}_{\mathrm{EM}}$ (CD45RA-CD62L-), and $\mathrm{T}_{\mathrm{EF}}$ (CD45RA+ CD62L-). The distribution of $\mathrm{T}$ cell subsets revealed more $\mathrm{T}_{\mathrm{EM}}$ and $\mathrm{T}_{\mathrm{EF}}$ cells in the E007-burden mice, whereas more $\mathrm{T}_{\mathrm{SCM}}$ and $\mathrm{T}_{\mathrm{CM}}$ cells in the E001-burden mice (Fig. 5b). As $\mathrm{T}_{\mathrm{EM}}$ and $\mathrm{T}_{\mathrm{EF}}$ cells are at terminal differentiation stage while $\mathrm{T}_{\mathrm{SCM}}$ and $\mathrm{T}_{\mathrm{CM}}$ cells at early differentiation stage, our findings suggested the E007-specific $\mathrm{T}_{\mathrm{SCM}}$ cells differentiated into the other $\mathrm{T}$ cell subsets when they came cross the same antigen in the E007 burden mice.

To analyze killing efficacy of the $\mathrm{T}_{\mathrm{SCM}}$ cells in vivo, on day 35 of the $\mathrm{T}$ cell treatment, the residual LCL cells in mice were detected by intracellular LMP1 staining. The LCL cells were mainly found in the spleen and bone marrow of the LCL-burden mice. In the E007-burden mice, the residual LCL cells in spleen and bone marrow of the $\mathrm{T}_{\mathrm{SCM}^{-}}$-treated mice were similar to that of the control mice without LCL infusion (control). Nevertheless, the $\mathrm{T}_{\mathrm{EM}+}$ EF-treated mice carried a significant amount of the residual LCL cells compared to the control mice, but the amount was lower than the E007-burden mice without $\mathrm{T}$ cell treatment (E007) (Fig. 6a-C). More residual LCL cells were also found in the immunofluorescent spleen sections of the $\mathrm{T}_{\mathrm{EM}}$ $+\mathrm{EF}^{-}$treated mice than those of the $\mathrm{T}_{\mathrm{SCM}^{-}}$-treated mice (Fig. 6d, e) These data demonstrated the $\mathrm{T}_{\mathrm{SCM}}$ cells equipped with superior capacity of killing targets of specific antigens in vivo compared to the $\mathrm{T}_{\mathrm{EM}}$ and $\mathrm{T}_{\mathrm{EF}}$ cells.

In contrast to the E007-burden mice, the E001-burden mice bore not only less $\mathrm{T}_{\mathrm{EM}}$ and $\mathrm{T}_{\mathrm{EF}}$ cells after the $\mathrm{T}_{\mathrm{SCM}}$ treatment, but also the residual LCL cells as high as that of the E007-burden mice without $\mathrm{T}$ cell treatment (Fig. 6a-c). Results of immunofluorescence staining of spleen sections for human T cells and LCLs showed residual LCL cells in E007-burden mice treated with $\mathrm{T}_{\mathrm{SCM}}$ were similar to those of the control mice. Although the spleen of the E001-burden mice showed a significant number of human $\mathrm{T}$ cells, the residual LCL cells were similar to that of the E007-burden mice without $\mathrm{T}$ cell treatment (Fig. 6d, e). By the way, the human $\mathrm{T}$ cell-treated mice showed no sign of xenogeneic graft-versus-host disease (xeno-GVHD), such as loss of body weight, back arched, and shed. Collectively, these results indicated that the prepared $\mathrm{T}_{\mathrm{SCM}}$ cells were able to survive over a long-term in vivo and differentiate into effector $\mathrm{T}$ cells to eradicate the target bearing the $\operatorname{cog}$ nate antigens.

\section{Discussion}

Mature $\mathrm{T}$ cells are comprised of cells that are at various stages of differentiation, which are discernible by the expression of surface molecules. $\mathrm{T}_{\mathrm{N}}$ cells are 


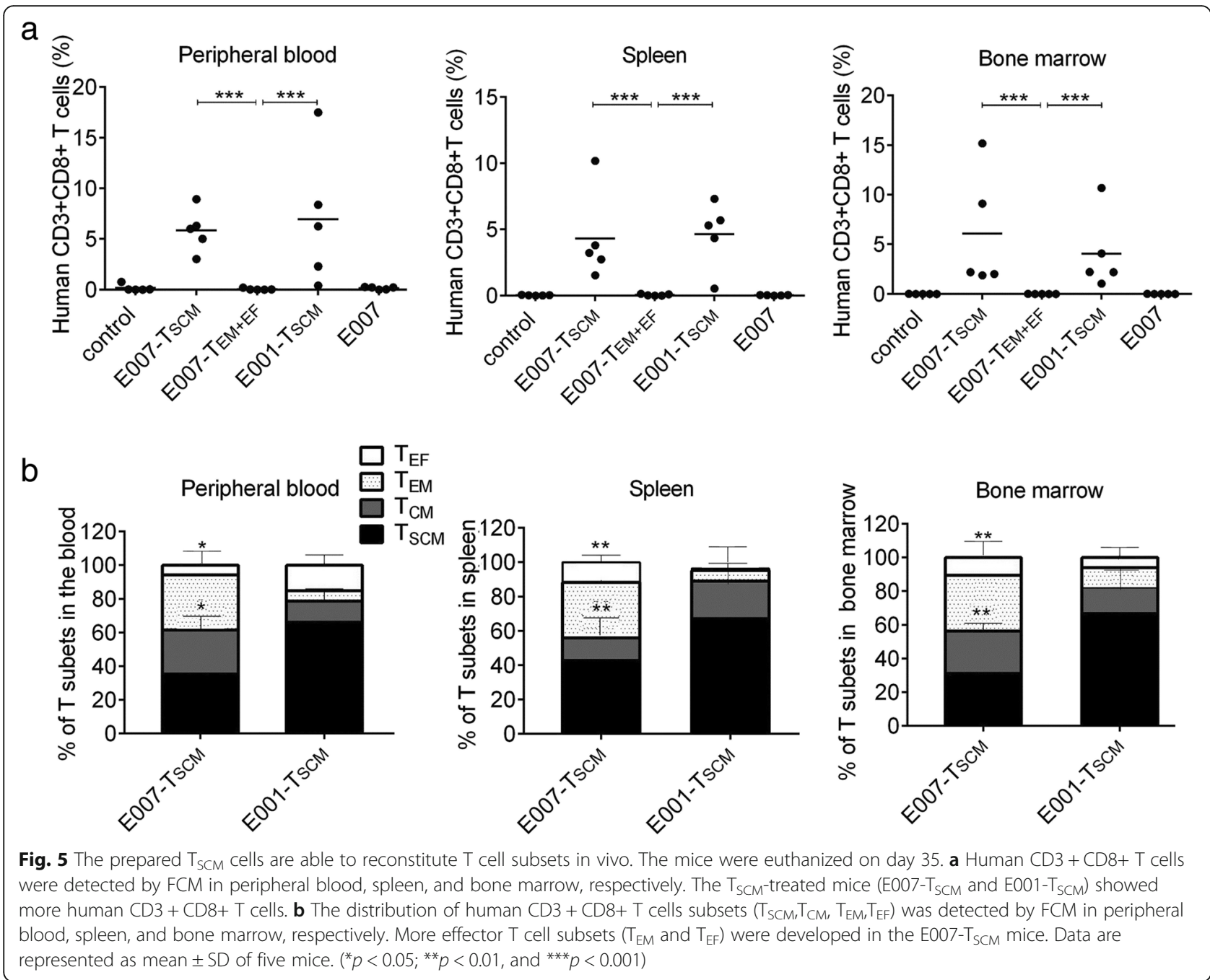

conventionally defined by the co-expression of the CD45RA, CCR7, and the lymph node homing molecules L-selectin (CD62L) [3]. Similar to $\mathrm{T}_{\mathrm{N}}$ cells, CD62L and CCR7 are maintained on $\mathrm{T}_{\mathrm{CM}}$ cells, whereas these molecules are lost on more differentiated $\mathrm{T}_{\mathrm{EM}}$ cells $[3,35]$. $\mathrm{T}_{\mathrm{SCM}}$ cells, the least differentiated of all distinct memory populations, are identifiable through the expression of markers, including CD62L, CCR7, CD95, and the chemokine (C-X-C motif) receptor $3[5,10,36]$. Naïve $T$ cells downregulate CD62L expression after stimulation, as clonal expansion goes on, both $\mathrm{CD} 62 \mathrm{~L}^{\mathrm{LOW}}$ and CD62L ${ }^{\mathrm{HIGH}} \mathrm{T}$ cell subsets are developed. With real-time tracking of CD8 T-cell divisions in vitro, Kinjyo and co-workers define memory $\mathrm{T}$ cells among CD62L $\mathrm{L}^{\mathrm{HIGH}}$ cells. The memory $\mathrm{T}$ cells stay CD62 $\mathrm{L}^{\mathrm{HIGH}}$ and proliferate in vitro driven by IL-2, although the division duration is slow, the phenotype and cell cycle duration are inherited by the progeny of the T cells [37]. We identified $\mathrm{CD} 8+\mathrm{T}_{\mathrm{SCM}}$ subset in the co-culture bulks by the phenotypes CD3+ CD8+ CD45RA+ CD62L+ CCR7+
CD95+ CD28+, as our results showed the cells with the phenotypes in the co-culture bulks were of stem cell and memory T cell properties.

A frequently used method to enrich $\mathrm{T}_{\mathrm{SCM}}$ cells is differentiation inhibition. With antigen priming, antigen-specific CD8 $+\mathrm{T}_{\mathrm{N}}$ cells proliferate and develop into $\mathrm{T}_{\mathrm{SCM}}$ cells first and then the other subsets. It is reported that $\mathrm{T}_{\mathrm{SCM}}$ differentiation can be inhibited by TWS119, which inhibits the GSK-3 $\beta$ and activate Wnt/ $\beta$-catenin. The inhibition improves the maintenance of 'stemness' in mature memory CD8+ T cells which mediated a better anti-tumor response after transferred into mice $[15,38]$. Rapamycin is also reported to help the formation of $\mathrm{T}$ cell subset at an early stage of differentiation by modulation of mTOR signaling [39-41]. However, rapamycin tended to promote the generation of $\mathrm{T}_{\mathrm{CM}}$ cells in our study (Additional file 1: Figure S1C), in line with other report [41]. In our co-culture of E007 with allogeneic PBLs, the E007-specific $\mathrm{T}_{\mathrm{SCM}}$ cells were generated from $\mathrm{T}_{\mathrm{N}}$ and enriched in the presence of 


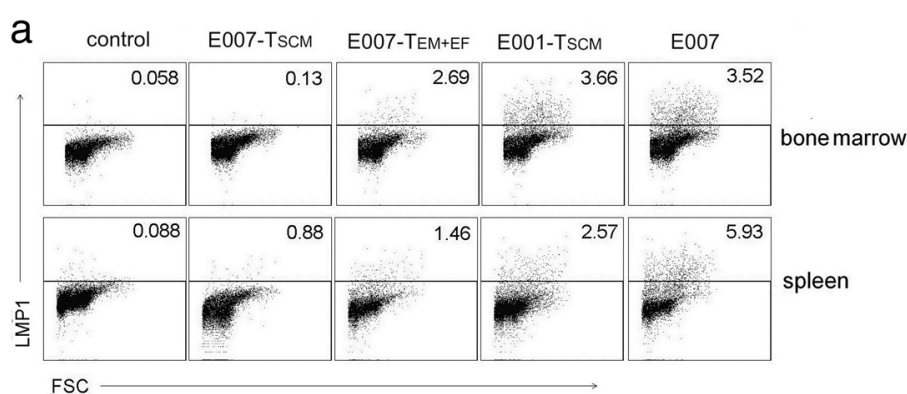

b

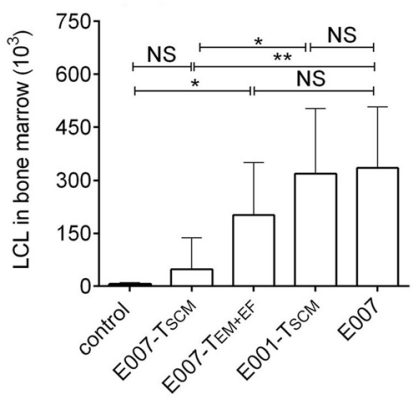

C

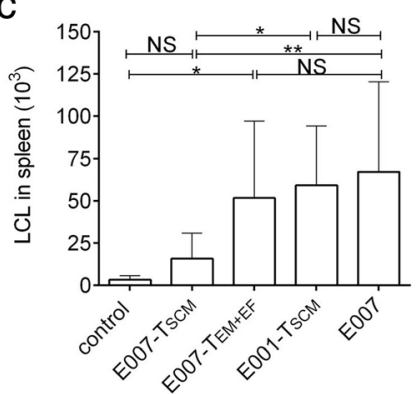

d control

E007-TSCM
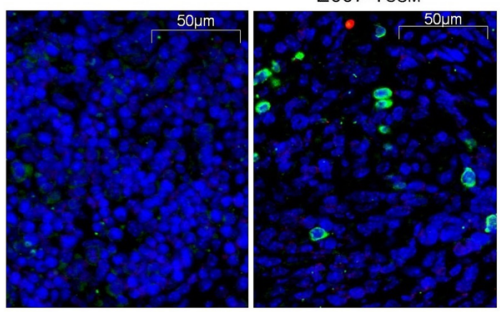

E007-TEM+EF
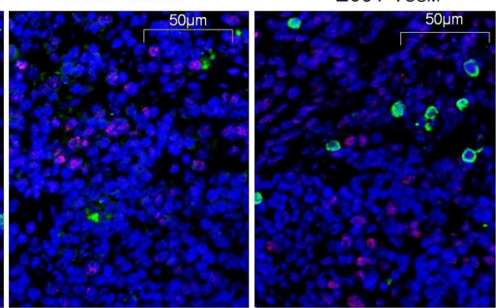

E007

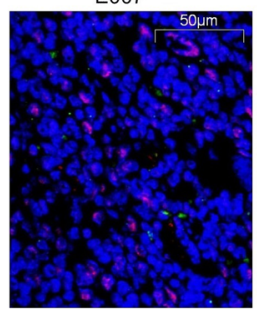

e

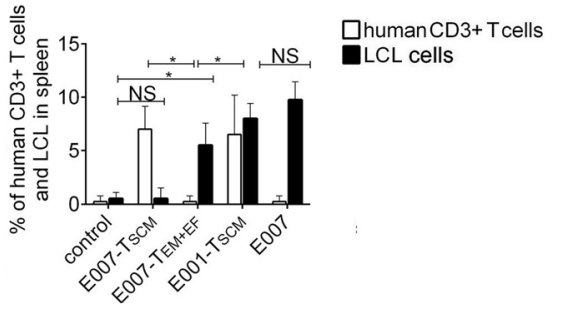

Fig. 6 The TSCM cells are able to eradicate allo-antigen-specific targets in vivo. The spleen and bone marrow were detected for the residual LCL cells by intracellular LMP1 staining using FCM. a-c Representative FCM plots (a) and the absolute number of LCLs in bone marrow of two femurs (b) and in $100 \mathrm{mg}$ spleen tissue (c) were analyzed. $\mathbf{d}$ Spleen sections were observed for LCLs and human T cells by immunofluorescence. Representative illustrations of immunofluorescent labeling of human CD3 (green), LMP1 (red), and nucleus staining by DAPI (blue) for spleen sections were shown $(\times 400)$. e Date showed the mean frequencies of human CD3 and LMP-1-positive cells in 4 fields chosen randomly (100 cells each) for each mouse spleen section. The residual LCLs in the E007-T SCM mice were similar to that in the control mice without $L C L$ inoculation, the rest mouse groups showed relatively more $L C L$ cells. Data are represented as mean \pm SD of five mice $\left({ }^{*} p<0.05 ;{ }^{* *} p<0.01 ;{ }^{* * *} p<0.001\right.$, and NS, $p>0.05$ )

TWS119 which inhibited the $\mathrm{T}_{\mathrm{SCM}}$ further differentiation. As inhibition by TWS119 results in a $\mathrm{T}_{\mathrm{SCM}}$ phenotype in human CD8+ T cells $[5,15,16]$, our protocol preferred expansion of CD8+ $\mathrm{T}_{\mathrm{SCM}}$ to that of CD4+ $\mathrm{T}_{\mathrm{SCM}}$.

The administration of cytokines is another method to expand $\mathrm{T}_{\mathrm{SCM}}$. Cytokines have important functions related to $\mathrm{T}$ cell expansion, differentiation, survival, and homeostasis. Common $\gamma$-chain $(\gamma c)$ family cytokines are commonly used in clinical trials, including IL-2, IL-7, IL-15, and IL-21. IL-7 is instrumental for the generation of $\mathrm{T}_{\mathrm{SCM}}$ cells by binding to IL-7 receptor expressing naive and memory $\mathrm{T}$ lymphocytes $[42,43]$. Expansion of $\mathrm{T}_{\mathrm{SCM}}$ required either IL-15 or IL-2; IL-15 proves superior to IL-2 in supporting expansion coupled to preservation of the $\mathrm{T}_{\mathrm{SCM}}$ phenotype $[18,19]$. Activated naive $\mathrm{T}$ 
cells show a higher expression of IL-21 receptor, and IL-21 has been reported to be able to enrich less differentiated $\mathrm{T}_{\mathrm{SCM}}$ within the total $\mathrm{T}_{\mathrm{SCM}}$ subset $[20,22,23$, 44]. However, IL-21 exerted few effects on the $\mathrm{T}_{\mathrm{SCM}}$ expansion in our study. Therefore, IL-7 and IL-15 were used to expand the $\mathrm{T}_{\mathrm{SCM}}$ cells after the proliferation sorting, resulting in a large number of the $\mathrm{T}_{\mathrm{SCM}}$ sufficient for the experiments in vitro and in vivo included in our study.

An important feature of stem cells is the self-renewal capacity. Although self-renewal abilities of the prepared $\mathrm{T}_{\mathrm{SCM}}$ cells were revealed by TREC copy numbers and proliferative history driven by IL-2 in vitro, long-term in vivo implantation is the gold standard for identification of stem cells. Long-lasting survival of human $\mathrm{T}_{\mathrm{SCM}}$ cells in mice is reported. In serial transplantations model, $\mathrm{T}_{\mathrm{SCM}}$ cells prove able to persist in secondary recipients suggesting self-renewal abilities [5, 6, 19, 45]. Here, the prepared $\mathrm{T}_{\mathrm{SCM}}$ migrated to secondary lymphoid organs, such as bone marrow and spleen, showed long-lasting survival potential at least for 35 days after transferred in our model. Importantly, the number of $\mathrm{T}_{\mathrm{SCM}}$ cells in the blood samples was observed consistent during this study, suggesting the self-renewal capacity of the transferred $\mathrm{T}_{\mathrm{SCM}}$ cells in vivo. The implantation and long-term existence of the $\mathrm{T}_{\mathrm{SCM}}$ cells in the host would be expected to mount durable $\mathrm{T}$ cell responses after transferring.

Governing antigen specificity is important for $\mathrm{T}_{\mathrm{SCM}}$ preparation; various strategies are used for this purpose. For example, HCMV-specific $\mathrm{T}_{\mathrm{SCM}}$ cells are isolated from peripheral blood $\mathrm{T}_{\mathrm{SCM}}$ cells of HCMV seropositive donors and enriched in vitro by incubation with HCMV antigen [26]. CD19-specific $\mathrm{T}_{\mathrm{SCM}}$ cells are prepared from peripheral blood $\mathrm{T}_{\mathrm{N}}$ and $\mathrm{T}_{\mathrm{SCM}}$ by transduction with a $\gamma$-retroviral vector encoding the CD19-chimeric antigen receptor (CAR) [24]. TCR-transgenic mice are also a source of antigen-specific $\mathrm{T}_{\mathrm{SCM}}$ cells [46]. In our approach, the E007-specific T cells underwent proliferation in the co-culture bulks, making it feasible to be sorted by CFSE dilution. In our pre-experiment, IL-7 or IL-15 was able to make PBLs proliferation without the E007 stimulation. Hence, no cytokine was added to the co-culture before the sorting, to ensure the E007-specificity of the prepared $\mathrm{T}_{\mathrm{SCM}}$ cells.

Two HLA class I mismatched LCLs, E007 and E001, were used to examine the antigen specificity of the prepared $\mathrm{CD} 8+\mathrm{T}_{\mathrm{SCM}}$ cells. Rapid differentiation into effector $\mathrm{T}$ cells and robust effector functions were observed when the prepared $\mathrm{T}_{\mathrm{SCM}}$ cells were stimulated with the E007, but not with the E001. Although the E007-specificity was suggested by these in vitro findings, it would be more important to observe the behavior of the prepared $\mathrm{T}_{\mathrm{SCM}}$ cells in vivo. In our LCL burden mouse model, LCL cells could be found in spleen and bone marrow up to 45 days after transfer into the immunodeficiency mice in our preliminary test. The LCL burden mice showed no measurable side effect during our study, such as loss of body weight, back arched, and shed. Interestingly, the prepared $\mathrm{T}_{\mathrm{SCM}}$ cells exhibited intensive differentiation into other $\mathrm{T}$ cell subsets and effective eradication of LCL targets in the E007-burden mice instead of the E001-burden mice. These observations reflected the prepared $\mathrm{T}_{\mathrm{SCM}}$ cells were E007-specific.

\section{Conclusions}

Functional allo-specific CD8 $+\mathrm{T}_{\mathrm{SCM}}$ cells were prepared from human PBLs in a procedure of allogeneic co-culture, differentiation inhibition, proliferation sorting, and cytokine expansion. Although our study provided a practical protocol for allo-specific $\mathrm{T}_{\mathrm{SCM}}$ cell preparation, this method would be adapted to prepare $\mathrm{T}_{\mathrm{SCM}}$ cells specific for antigen of interesting. As $\mathrm{T}_{\mathrm{SCM}}$ cells show the implantation and long-term existence in the host after transferring, the preparation of antigen-specific $\mathrm{T}_{\mathrm{SCM}}$ cells is crucial for $\mathrm{T}$ cell adoptive immunotherapy.

\section{Additional files}

Additional file 1: Figure S1. Enrichment of $\mathrm{T}_{\mathrm{SCM}}$ cells by differentiation inhibitors and the lymphocyte distribution changes in the cultural bulks over the $T_{\text {scm }}$ preparation course. A, B TWS119 exhibited concentrationdependent enrichment of $\mathrm{T}_{\mathrm{SCM}}$ in the alloreactive co-culture, $5 \mu \mathrm{M}$ of TWS119 was the best concentration. Tscm cells in frequency $(\mathbf{A})$ and in absolute number (B) were shown. $\mathbf{C}$ Differentiation inhibition by rapamycin was more likely to enrich $T_{C M}$ instead of $T_{S C M}$. D-F After allogeneic activation, differentiation inhibition, proliferation sorting, and cytokine expansion, lymphocyte distribution in the cultural bulks was revealed by FCM over the $T_{\text {SCM }}$ preparation course. $C D 3+C D 4+T$ cells, CD3 + CD8 + $T$ cells and CD3- cells in the cultural bulks were detected, and the proportion of CD3 + CD8+ T cells was increased over time (D). The majority of cultural bulks were CD3 + CD8+ $T_{\text {SCM }}(60.1 \pm 11.2 \%)$ on day $14(\mathbf{E})$. The proportion of CD3 + CD8 $+T_{5 C M}$ in CD8 $+T$ cells was increased over time, about $80 \%$ of CD8+ T cells were $T_{\text {SCM }}$ on day $14(\mathbf{F})$. Data are represented as mean \pm SD of four individual experiments. (JPG $170 \mathrm{~kb}$ )

Additional file 2: Figure S2. Our $\mathrm{T}_{\mathrm{SCM}}$ preparation strategy can be used to generate a single epitope-specific $T_{S C M}$ cells. A Procedure for preparation of AFP-specific, allogeneic $T_{S C M}$. T2 cells express only empty HLA-A2 allele and no other HLA allele. Alpha fetoprotein (AFP) is a tumor associated antigen of hepatocarcinoma, the hAFP ${ }_{158-166}$ (FMNKFIYEI) is an HLA$A 2$ restricted peptide. When pulsed with the AFP peptide, T2 cells were able to present the AFP/HLA-A2 complex. The AFP-specific $T_{S C M}$ were raised by co-culturing HLA-A2 negative (HLA-A2-ve) PBLs and the T2 cells pulsed with the AFP peptide (T2/AFP). In a procedure of an allogeneic co-culture, differentiation inhibition, proliferation sorting and cytokine expansion, the AFP/HLA-A2 complex-specific $\mathrm{T}_{\mathrm{SCM}}$ cells were produced. $\mathbf{B}$ Co-culture by mixing of $1 \times 10^{7} \mathrm{PBLS}$ and $2 \times 10^{6} \mathrm{~T} 2$ /AFP on day 0 , a prolonged cytokine expansion was required to generate $1 \times 10^{6}$ AFP-specific $T$ cells. Data are represented as mean \pm SD of four individual experiments. C-E The prepared $T_{S C M}$ cells were AFP-specific. The prepared TSCM cells were incubated with the T2/AFP and T2 cells pulsed with an irrelevant peptide $\mathrm{HBCAg}_{18-27}(\mathrm{~T} 2 / \mathrm{HBC})$, respectively. After $4 \mathrm{~h}$ incubation, the $\mathrm{T}$ cell subsets and their intracellular IFN- $\gamma$ production were detected. 
Representative FCM plots (C). Tscm cells differentiated more when incubated with the T2/AFP (D). The daughter cells showed more frequent IFN- $\gamma$ positive cells when incubated with the T2/AFP (E). Data are represented as mean \pm SD of four individual experiments $\left({ }^{* *} p<0.01\right)$. (JPG $404 \mathrm{~kb}$ )

Additional file 3: Figure S3. The prepared $\mathrm{T}_{\mathrm{SCM}}$ differentiated into effector T cells stimulated by E007. The prepared $T_{S C M}$ were stimulated with E007, E001 and a-CD3/CD28, respectively. The T cell subsets and their intracellular IL-2, TNF- $a$ and IFN- $\gamma$ production were detected. The $T_{S C M}$ differentiated into effector $T$ cells upon the stimulation with E007 and a-CD3/CD28. A-D After 4-h stimulation, both $T_{E M}$ and $T_{E F}$ cells exhibited the similar frequency of the cytokine positive cells. Representative FCM plots (A). Gating by CD3+ CD8+ CD62L-, the T cells were divided into CD45RA- ( $\left.T_{E M}\right)$ and CD45RA+ ( $\left.T_{E F}\right)$ cells. The $T_{E M}$ and $T_{E F}$ subsets showed the cytokine positively stained cells of IFN- $\gamma(\mathbf{B})$, TNF- $a(\mathbf{C})$ and IL2 (D). E After 24-h stimulation, the absolute number of $T_{S C M}$ remained stable during differentiation. F, G The cytotoxicity of the $T_{\mathrm{Scm}}$ and the daughter cells were E007-specific. E007 and E001 labeled with celltrace, co-cultured with the $\mathrm{T}_{\mathrm{scm}}$ at ratio 1:5. Dead cells stained by PI dye were detected by FCM. Representative FCM plots $(\mathbf{F})$ and the frequencies of dead cells $(\mathbf{G})$ were shown. Data are represented as mean \pm SD of four individual experiments (NS, $p>0.05 ;{ }^{* *} p<0.01$, and ${ }^{* * *} p<0.001$ ). (JPG $722 \mathrm{~kb})$

\section{Abbreviations}

ACT: Adoptive cell therapy; GVHD: Graft versus host disease; HLA: Human leukocyte antigen; LCL: B lymphoblastoid cell lines; LMP1: Latent membrane protein 1; PBL: Peripheral blood lymphocytes; PBMC: Peripheral blood mononuclear cells; pMHC: Peptide major histocompatibility complex; TCR: T cell receptor; TREC: T cell receptor rearrangement excision circle

\section{Acknowledgements}

The authors apologize to colleagues whose work could not be cited because of space limitation. They thank Dr. Jinghui Zhang (The Union Hospital, Tongji Medical College, Huazhong University of Science and Technology) for the FACS sorting in this study.

\section{Funding}

This project was supported by the National Natural Science Foundation of China (no. 31370885).

\section{Availability of data and materials}

Please contact author for data requests.

\section{Authors' contributions}

XWW designed the study, analyzed the data, and wrote the manuscript. LG was a major contributor in the experimental performance, analyzed the data, and wrote the manuscript. XL performed and analyzed the cell culture experiments. JW contributed to the animal experimental performance. XFW contributed to the design of study. ZL contributed to the data analysis. JY contributed to the manuscript preparation. All authors read and approved the final manuscript.

\section{Ethics approval}

All donors' samples were obtained after informed consent according to a protocol approved by the Ethics Committee of Tongji Medical College, Wuhan, China. Animal experiments were approved by the Ethics Committee of Tongji Medical College. All animal procedures were performed in strict accordance with the guidelines of the Chinese Council on Animal Care.

\section{Consent for publication}

Not applicable.

\section{Competing interests}

The authors declare that they have no competing interests.

\section{Publisher's Note}

Springer Nature remains neutral with regard to jurisdictional claims in published maps and institutional affiliations.
Received: 1 May 2018 Revised: 12 November 2018

Accepted: 19 November 2018 Published online: 07 December 2018

\section{References}

1. June CH. Principles of adoptive T cell cancer therapy. J Clin Invest. 2007;117: 1204-12.

2. Restifo NP, Dudley ME, Rosenberg SA. Adoptive immunotherapy for cancer: harnessing the T cell response. Nat Rev Immunol. 2012;12:269-81.

3. De Rosa SC, Herzenberg LA, Roederer M. 11-color, 13-parameter flow cytometry: identification of human naive T cells by phenotype, function, and T-cell receptor diversity. Nat Med. 2001;7:245-8.

4. Mahnke YD, Brodie TM, Sallusto F, Roederer M, Lugli E. The who's who of Tcell differentiation: human memory T-cell subsets. Eur J Immunol. 2013;43: 2797-809.

5. Gattinoni L, Lugli E, Ji Y, Pos Z, Paulos CM, Quigley MF, et al. A human memory T cell subset with stem cell-like properties. Nat Med. 2011;17:12907.

6. Cieri N, Camisa B, Cocchiarella F, Forcato M, Provasi E, Bondanza A, et al. IL7 and IL-15 instruct the generation of human memory stem $T$ cells from naive precursors. Blood. 2013;121:573-84

7. Biasco L, Scala S, Basso Ricci L, Dionisio F, Baricord C, Calabria A, et al. In vivo tracking of T cells in humans unveils decade-long survival and activity of genetically modifed T memory stem cells. Sci Transl Med. 2015. https:// doi.org/scitranslmed/scitranslmed 3010314.

8. Lugli E, Gattinoni L, Roberto A, Mavilio D, Price DA, Restifo NP, Roederer M. Identification, isolation and in vitro expansion of human and nonhuman primate T stem cell memory cells. Nat Protoc. 2013;8:33-42.

9. Flynn JK, Gorry PR. Stem memory T cells $\left(T_{\text {SCM }}\right)$-their role in cancer and HIV immunotherapies. Clin Transl Immunology. 2014. https://doi.org/10.1038/cti.

10. Gattinoni L, Klebanoff CA, Restifo NP. Paths to stemness: building the ultimate antitumour T cell. Nat Rev Cancer. 2012;12:671-84.

11. Xu L, Zhang Y, Luo G, Li Y. The role of stem cell memory T cells in hematological malignancies. J Hematol Oncol. 2015. https://doi.org/10.1186/ s13045-015-0214-5.

12. Lugli E, Dominguez MH, Gattinoni L, Chattopadhyay PK, Bolton DL, Song K, et al. Superior T memory stem cell persistence supports long-lived T cell memory. J Clin Invest. 2013:123:594-9.

13. Fuertes Marraco SA, Soneson C, Caqnon L, Gannon PO, Allard M, Allard Maillard S, et al. Long-lasting stem cell-like memory CD8+ T cells with a naive-like profile upon yellow fever vaccination. Sci Transl Med. 2015. https://doi.org/scitranslmed/scitranslmed aaa3700.

14. Morrot A. Lifelong protection mediated by stem cell-like CD8(+) T memory subset cells $\left(\mathrm{T}_{\mathrm{SCM}}\right)$ induced by vaccination. Ann Transl Med 2016; doi: https://doi.org/10.21037/atm.2016.05.38.

15. Gattinoni L, Zhong XS, Palmer DC, Ji Y, Hinrichs CS, Yu Z, et al. Wnt signaling arrests effector $T$ cell differentiation and generates CD8+ memory stem cells. Nat Med. 2009;15:808-13.

16. Forget MA, Huon $Y$, Reuben A. Stimulation of Wnt/B-catenin pathway in human CD8+ T lymphocytes from blood and lung tumors leads to a shared young/memory phenotype. PLoS One. 2012. https://doi.org/10.1371/journal. pone. 0041074.

17. Muralidharan S, Hanley PJ, Liu E, Chakraborty R, Bollard C, Shpall E, et al. Activation of Wht signaling arrests effector differentiation in human peripheral and cord blood-derived T lymphocytes. J Immunol. 2011;187: 5221-32.

18. Cieri N, Camisa B, Cocchiarella F, Forcato M, Oliveria G, Provasi E, et al. IL-7 and IL-15 instruct the generation of human memory stem $T$ cells from naive precursors. Blood. 2013;121:573-84.

19. Xu Y, Zhang M, Ramos CA, Durett A, Liu E, Dakhova O, et al. Closely related T-memory stem cells correlate with in vivo expansion of CAR CD19-T cells and are preserved by IL-7 and IL-15. Blood. 2014;123:3750-9.

20. Lugli E, Goldman CK, Perera LP, Smedley J, Yovandich JL, Creekmore SP, et al. Transient and persistent effects of $\mathrm{IL}-15$ on lymphocyte homeostasis in nonhuman primates. Blood. 2010;116:3238-48.

21. Alvarez-Fernandez C, Escriba-Garcia L, Vidal S, Sierra J, Briones J. A short CD3/CD28 costimulation combined with IL-21 enhance the generation of human memory stem $T$ cells for adoptive immunotherapy. J Transl Med. 2016. https://doi.org/10.1186/s12967-016-0973-y.

22. Zeng R, Spolski R, Finkelstein SE, Oh S, Kovanen PE, Hinrichs CS, et al. Synergy of IL-21 and IL-15 in regulating CD8+ T cell expansion and function. J Exp Med. 2011;201:139-48. 
23. Pilipow K, Roberto A, Roederer M, Waldmann TA, Mavilio D, Lugli E. IL-15 and T-cell Stemness in T-cell-based Cancer immunotherapy. Cancer Res. 2015;75:5187-93.

24. Sabatino M, Hu J, Sommariva M, Gautam S, Fellowes V, Hocker JD, et al. Generation of clinical-grade CD19-specific CAR-modified CD8+ memory stem cells for the treatment of human B-cell malignancies. Blood. 2016;128: 519-28

25. Albrecht J, Frey M, Teschner D, Carbol A, Theobald M, Distler E. IL-21treated naive CD45RA+ CD8+T cells represent a reliable source for producing leukemia-reactive cytotoxic T lymphocytes with high proliferative potential and early differentiation phenotype. Cancer Immunol Immunother. 2011;60:235-48.

26. Schmueck-Henneresse M, Sharaf R, Vogt K, Weist BJ, Landwehr-Kenzel S, Fuehrer $H$, et al. Peripheral blood-derived virus-specific memory stem $T$ cells mature to functional effector memory subsets with self- renewal potency. J Immunol. 2015;194:5559-67.

27. Yang I, Weiss L, Abdul-Hai A, Kasir J, Reich S, Slavin S. Induction of early post-transplant graft-versus-leukemia effects using intentionally mismatched on or lymphocytes and elimination of alloantigen-primed donor lymphocytes for prevention of graft-versus-host disease. Cancer Res. 2005; 65:9735-40.

28. Amir AL, van der Steen DM, Hagedoorn RS, Kester MG, van Bergen CA, Drijfhout JW, et al. Allo-HLA-reactive T cells inducing graft-versus-host disease are single peptide specific. Blood. 2011;118:6733-42.

29. $Y u$ Q, Zhang L, Ouyang LC, Gong YL, Liang ZH, Shen GX, et al. A similarity in peptide cross-reactivity between alloantigen and nominal antigeninduced CD8+ T cell responses in vitro. Immunogenetics. 2013;65:173-84.

30. Tsirigotis $P$, Shimoni A, Nagler A. The expanding horizon of immunotherapy in the treatment of malignant disorders: allogeneic hematopoietic stem cell transplantation and beyond. Ann Med. 2014;46:384-96.

31. Negrin RS. Graft-versus-host disease versus graft-versus-leukemia. Hematology Am Soc Hematol Educ Program. 2015;1:225-30.

32. Neitzel H. A routine method for the establishment of permanent growing lymphoblastoid cell lines. Hum Genet. 1986;73:320-6.

33. Bunce M, O'Neill CM, Barnardo MC, Krausa P, Browning MJ, Morris PJ, et al. Phototyping: comprehensive DNA typing for HLA-A, B, C, DRB1, DRB3, DRB4, DRB5 \& DQB1 by PCR with 144 primer mixes utilizing sequencespecific primers (PCR-SSP). Tissue Antigens. 1995;46:355-67.

34. Lang PO, Mitchell WA, Govind S, Aspinall R. Real time-PCR assay estimating the naive T-cell pool in whole blood and dried blood spot samples: pilot study in young adults. J Immunol Methods. 2011;369:133-40.

35. Weninger W, Crowley MA, Manjunath N, von Andrian UH. Migratory properties of naive, effector, and memory CD8+ T cells. J Exp Med. 2001; 194:953-66.

36. Sallusto F, Lenig D, Forster R, Lipp M, Lanzavecchia A. Two subsets of memory $T$ lymphocytes with distinct homing potentials and effector functions. Nature. 1999;40:708-12.

37. Kinjyo I, Qin J, Tan SY, Wellard CJ, Mrass P, Ritchie W, et al. Real-time tracking of cell cycle progression during CD8+ effector and memory T-cell differentiation. Nat Commun. 2015. https://doi.org/10.1038/ncomms7301.

38. Gattinoni $L$, Ji $Y$, Restifo NP. WNT/B-catenin signaling in T-cell immunity and cancer immunotherapy. Clin Cancer Res. 2010;16:4695-701.

39. Scholz G, Jandus C, Zhang L, Grandclement C, Lopez-Mejia C, Soneson C, et al. Modulation of $\mathrm{mTORC}$ signaling triggers the formation of stem cell-like memory T cells. EBioMedicine. 2016:4:50-61.

40. Chi H. Regulation and function of mTOR signalling in $T$ cell fate decisions. Nat Rev Immunol. 2012;12:325-38.

41. Araki K, Turner AP, Shaffer VO, Gangappa S, Keller SA, Bachmann MF, et al. mTOR regulates memory CD8 T-cell differentiation. Nature. 2009;460:108-12.

42. Tan JT, Dudl E, LeRoy E, LeRoy E, Murray R, Sprent J, et al. IL-7 is critical for homeostatic proliferation and survival of naive T cells. Proc Natl Acad Sci U S A. 2001;98:8732-7.

43. Boyman O, Letourneau S, Krieg C, Sprent J. Homeostatic proliferation and survival of naive and memory T cells. Eur J Immunol. 2009;39:2088-94.

44. Battaglia A, Buzzonetti A, Baranello C, Fanelli M, Fossati M, Catzola V, et al. Interleukin-21 (IL-21) synergizes with IL-2 to enhance T-cell receptorinduced human T-cell proliferation and counteracts IL-2/transforming growth factor-beta-induced regulatory T-cell development. Immunology. 2013;139:109-20
45. Kagoya Y, Nakatsugawa M, Ochi T, Cen Y, Guo T, Anczurowski M, Saso K, et al. Transient stimulation expands superior antitumor T cells for adoptive therapy. JCl insight. 2017. https://doi.org/10.1172/jci. insight. 89580.

46. Stemberger C, Graef $\mathrm{P}$, Odendahl M, Albrecht J, Dossinger G, Anderl F, et al. Lowest numbers of primary CD8 (+) T cells can reconstitute protective immunity upon adoptive immunotherapy. Blood. 2014;124:628-37.

\section{Ready to submit your research? Choose BMC and benefit from:}

- fast, convenient online submission

- thorough peer review by experienced researchers in your field

- rapid publication on acceptance

- support for research data, including large and complex data types

- gold Open Access which fosters wider collaboration and increased citations

- maximum visibility for your research: over $100 \mathrm{M}$ website views per year

At BMC, research is always in progress.

Learn more biomedcentral.com/submissions 